\title{
SUITABILITY OF THE PRESENT STRATEGIC INFORMATION TECHNOLOGY PLANNING (SITP) METHODOLOGIES TO THE DEVELOPING COUNTRIES
}

\author{
M.A.M. Victor \\ Dept. of Mechanical Engineering, University of Dar es Salaam, \\ P.O.Box 35131, Dar es Salaam, Tanzania
}

\section{ABSTRACT}

The need for strategy formulation, or in general terms strategic planning, for IT is considered as one of the most important aspects of IT management. To this end, there are a number of IT strategy formulation methodologies world-wide. These methodologies were developed over a span of time, starting from mid 1960's when IT use started to become a serious issue in the cieveloped countries, anc' continued with the trends in IT development and use, as was applicable in those countries. More recent of the methodologies were developed through improvements on earlier ones, and based on the new challenges which were brought tip by the very fast developinents in IT. By analysing the general problems associated with these methodologies, the author concludes that there is only one basic problem with Strategic Information Technology Planning (SITP) niethodologies, which is to consider them as full fledged methodologies rather than touls for developing SITP methodologies. With this conclusion the author makes a second conclusion that, as far as SITP tools are concerned, their suitalility depends on proper selection of a combination of ihem depending on the specific industry requirements, whether located in developing or developed countries.

\section{INTRODUCTION}

Strategic planning is concened with long term prosperity and it is aimed at ensuring that the business is still around in ten or twenty years time. It is concerned with long term asset growth, not short term profit, and therefore its purpose is not iest perceived in terms of its impact on bottom line. Instead it can be identified in a more operational terms as setting the direc- 
tion of a business and thus achicving a concentration and consistency of effort. In this way inconsistent fitting from short term opportunity to short term opportunity is avoided and business expertise and leadership can be built up.

Perhaps the most crucial idea in strategic planning is that of setting a direction. Once a direction is set, it becomes possible to take decisions in a consistent manner with regard to strategy. Only when direction is set is it possible for all members of the business to know which way they are headed, and only then can they shape their own efforts accordingly. "In order to get there - direction, we need to know where we are now, where we want to get to, and, how we can get there" [Pearson, 1990].

When it comes to strategic information technology planning (SITP), various authors have provided their definitions or objectives for that process. SITP has been defined [Boynton and Zmud, 1987] as organisation activities directed toward (1) recognising organisational opportunities for using information technology (IT), (2) determining the resource requirements to exploit these opportunities, and (3) developing strategies and action plans for realising these opportunities and meeting the resource needs. IT resources include the hardware, software and personnel used in supporting electronically based information processing, including data, text, voice and image forms of information.

SITP is the process of deciding the objectives for organisational computing and identifying potential computer applications which the organisation should implement [Lederer and Sethi, 1988]. It therefore covers longrange directional planning of information systems, linking application of IT to business goals, resource forecasting, exploiting IT for strategic advantage, mapping future in frastructures, and allocating scarce IT resources.

Vitale et al. [1986], classified the objectives of IT strategic planning into two main groups:

1. Aligning IT objectives with organisational goals

2. Impacting organisational strategies with IT.

The first group consists of primary objectives of systems planning as were highlighted by McI cean and Soden [1977], and which includes: 
- $\quad$ to improve communication with users

- $\quad$ to increase top management support

- $\quad$ to better forecast resource requirements and allocate resources

- $\quad$ to determine more opportunities for improving the MIS department

- $\quad$ to identify new and higher pay-back computer applications.

The second group consists of cbjectives aimed at searching for applications with a high impact and the ability to create a competitive advantage over competitors [Clemens, 1986; Ives and Learmonth, 1984; McFarlan, 1984; Parsons, 1983; Wiseman, 1985]. IT may be used to help organisation produce at lower cost, to differentiate itself from its competitors, or to identify and concentratc on particular market segment [Porter, 1980; Porter and Millar, 1985]. These three strategies may be achieved by using IT to raise entry barriers, increase negotiating power with suppliers, create new dependencies for clients, offer new products or substitutes, and even change the grounds for competition or the nature of the stakes [McFarlan, 1984, Porter, 1979].

IT can be used strategically by an organisation in order to secure gains over its competitors [Bergeron et al., 1991]. IT for competitive advantage is defined as IT that drive or formulate the organisation's competitive strategy in order to provide it with (or to maintain) a competitive advantage [Wiseman, 1985]. To provide competitive advantage, IT must modify the structure of the industry, improve position of the firm, or create new business opportunities [Porter and Millar, 1985]. Basically, a competitive advantage is created when a firm increases its comparative efficiency or its bargaining power [Bakos and Treacy, 1986; Johnston and Vitale, 1988].

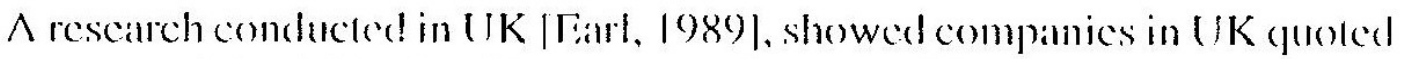
any one of the following four reasons for embarking on Sl'TP exercise:

1. Sector exploitation of IT is posing strateric threats and opportumi lics

2. The need to align investment in IT with husiness needs

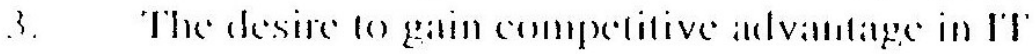

4. The revamping of IT function and elevation of IT activities. 
The first reason is common and quoted by most firms in the 'delivery' sector and many in the 'dependent' sector. In the delivery sector IT has become the means of delivering the goods and services while in the dependent sector the business and functional strategies are increasingly dependent upon IT for their implementation. Financial services and airlines can be considered as examples of the delivery sector while textile or automobile industry can be considered as examples of the dependent sector.

The second reason is dominant and reflects a top management concern for many years that specialists have decided both what systems to develop and how they should be designed. It also reflects on the understanding of business priorities. The third reason is more fragile and aims at looking at what is being done outside the firm in terms of discovering the power of IT and also aiming at a competitive position. The fourth reason provides an awareness that indeed IT can make a difference.

From the above views, it is possible to conclude that the expected outcome of SITP will essentially be a firm's IT directional statement showing strategically justified relative priorities within and among IT development portfolio elements on the basis of relative spending and schedule. It will be a perspective that gives direction and policies and sets aspiration levels on these portfolio elements. These portfolio elements will naturally consist of the IT applications and the IT infrastructure and will be known as "Applications Development Portfolio" (ADP).

Together with aiming at achicving consistency and concentration of efforts in IT matters by aligning IT objectives with business needs and seeking competitive advantages from IT through the above mentioned outcomes, and which could be considered as the 'hard' benefits, SITP is expected to bring about the following 'soft' benefits:

- improved top management support for I'T strategy

- improved resource loreciasting

- improved business planning

- $\quad$ improved user communication

- better understanding of the organisation/business.

It is from the aluwe differing? defonitions, whicetives and reasons behind

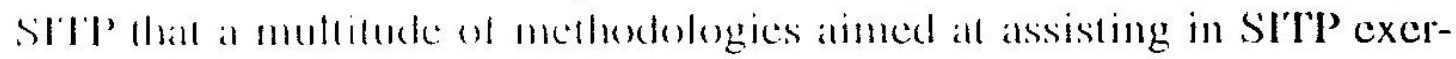


cise were formulated. The most important ones are summarised in section two of this paper. Since this papers is aimed at analysing the suitability of these methodologies for developing countries, the general problems associated with these methodologies are highlighted in section three, before analysing the current situation in the developing countries in relation with these general problems in section four. Concluding remarks are given at the end of the paper.

\section{IT STRATEGY FORMULATION METHODOLOGIES}

Formal information systems planning was first initiated at many firms in the mid 1960's [Sullivan, 1985; Boynton and Zmud, 1987]. Since then, a number of planning methodologies have been developed. The popular methodologies include Stages of Growth [Gibson and Nolan, 1974; Nolan, 1979; Sullivan, 1985], Business Systems Planning [Sullivan, 1985; Lederer and Putnam, 1987; Lederer and Sethi, 1988; Lee and Adams, 1990], Information Resource Management |Dichold, 1979: Truath, 1984; Sullivals, 1985], Critical Success Iactors [Danicl, 1961; Rockart, 1979; Munro and Wheeler, 1980; Bullen and Rockart, 1981; Martin, 1982; Rockart, 1982; Munro, 1983; Boynton and Znud, 1984; Shank et al., 19851, Strategic Set Transformation [King, 1978], Value Chain Analysis [Porter and Millar,

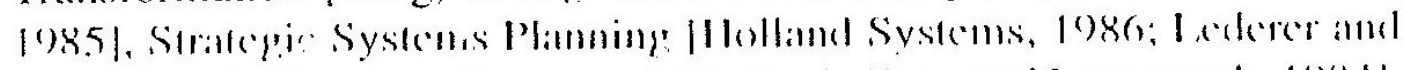

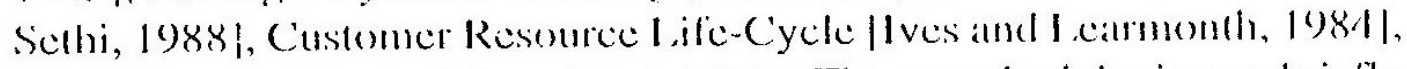
Three-Pronged Methodology [Earl, 1989|. These methodologies are briefly described lodow

Stages of Growth (SOG) stresses the importance of identifying the IT

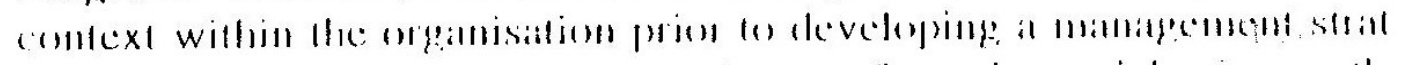
egy. The planning response was to borrow from the social sciences the notion that organisations must assimilate the changes brought about by the

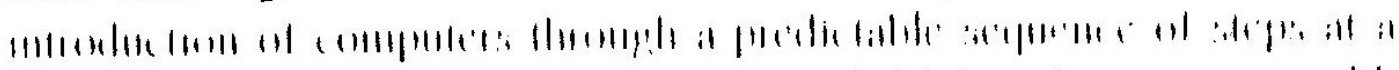
modest pale fSullivan. 19851. The theory held that the secplened, with

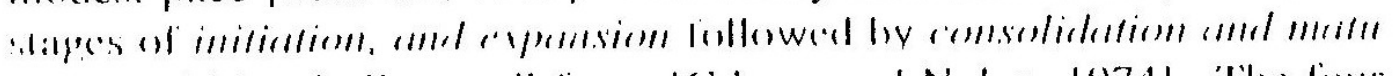
rity, would be similar all all lims [Cibson and Nolan, 1974). The fourstages werc later superseded by a six-stages approach, consisting of initiation, contagion. comtrol. integration, data administration and maturity $\mid N(1+i|l|,(1) \mid$.

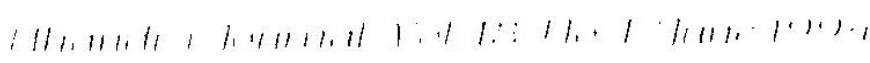


During the expansion of the stages of growth from four to six on the basis of increasing challenges, Nolan, [1979], suggested a three-step process for the development of an effective strategy and plan. First, management should determine where the company stands in the evolution of a DP function and should analyze the strengths and weaknesses that bear on DP strategies. Second, it should choose a DP strategy that fits in with the company's husiness strategy. And third, it should outline a DP growth plan for the next three to five years, detailing this plan for each of the growth processes identified.

Business Systems Planning (BSP). Perhaps the most well-known strategic systems planning tool known to the IS word is IBM's BSP methodology [Lee and Adams, 1990]. The methodology involves top-down planning with bottom-up implementation. In this methodology, a firm recognises its business mission, objectives and functions, and how these determine its business processes. The processes are analysed for their data needs, and data classes are then identified. Databases are developed by combining similar data classes. The final BSP plan describes an overall information system architecture as well as the installation schedule of individual systems [Lederer and Sethi, 1988].

Information Resource Management (IRM) was developed by combining the strength of both BSP and SOG methodologies. It retains the information focus of BSP, but brings back into planning process the management issues of organisational change and commitment(combining data resource planning of BSP with the management perspective of SOG) [Diebold, 1979; Truath, 1984]. The methodology works under the same assumption as that of BSP, that is, centralised environments [Sullivan, 1985].

Critical Success Factors (CSFs) are those few things that must go well to ensure success for a manager or an organisation, and therefore represent those managerial and enterprise areas that must be given special and continual attention to bring about high performance. As a methodology, CSF is a procedure that attempts to make explicit those few key areas that dictate managerial or organisational success [Rockart, 1979]. The primary focus of the methodology is upon the lexecutive's own experience and intuition in determining what lactors are truly critical to the success of his/ her firm. 
The scope of this methodology as a strategic planning tool depends upon the CSFs that are identified. If the CSFis include such factors as delivery of services, then the scope is external marketplace. If the CSFs identified include effective and efficient systems, then the scope is internal operattions [Lee and Adams, 1990).

Strategic Systems Planning (SSP), developed by Robert Holland, defines a business function model by analysing major functional areas. A data architecture is derived from the business function model by combining information requirements into generic data entities and subject databases. Any information systems architecture then identifies new systems and their implementation schedule [Holland Systems, 1986]. Although the language differs slightly, the steps in the SSP procedure are similar to those in BSP.

A major difference from BSP is SSP's automated storage, manipulation, and presentation of data collected during the planning process. Software produces reports in a wide range of formats and various !evels of detail [Lederer and Sethi, 1988]. For example "affinity" reports show the frequencies of accesses to data, while "clustering" reports give guidance for database design. Menus guide the user through on-line data coliection and maintenance. A data dictionary interface fecilitates sharing SSP data with an existing data dictionary or other automated design tools.

Strategic Set Transformation (SST) consists of general frameworks to discover business strategy set such as the mission and objectives, interpret it into IT necds and validate the results [King, 1978]. The methodology establishes the importance of linking IT planning to an organisation's strategic direction. The approach offers insights to practitioners on ways to build an effective link between an organisation's IT capabilities and strategy.

Value Chain Analysis (VCA) divide company's activities into technologically and economically distinct activities it performs to do business IPerter and Millar, 19851. These are called value atedivilies hecaluse they should add value for which huyers ate willing: to pay when they buy the final product or service heing supplied. A typical sed of activities for the

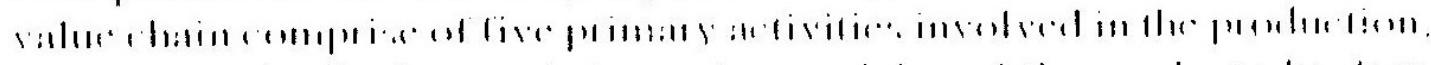
markeling, distribution, and alter sales servicing of the phedect flus foun 
support activities which provide the inputs and infrastructure that allow the primary activities to take place. The interdependent activities are then connected by linkages, which exists when one activity affects another in terms of cost or effectiveness and trade-offs and optimisation are sought to find the right blend to achieve competitive advantage. Also linkages require co-ordination. One firm's value chain, of course, is embedded in the collective value chains of both suppliers and customers in the industry, creating a stream of industrial 'value system' [Porter and Millar, 1985].

Every value activity creates and uses information of some kind [Porter and Millar, 1985]. A logistic activity, for example, uses information like scheduling promises, transportation rates, and production plans to ensure timely and cost-effective delivery. A commercial bank lending activity uses information about its possible customer such as his/her business plans, previous loan history, and even his lifestyle, to decide whether to offer the loan to the customer or not.

This type of analysis unfolds the scope of exploiting IT, which could be applying either technology directly or its information processing capability to either value activities or thcir linkages. These activities and their linkages are the means whereby a firm can seek to implement its cost leadership or differentiation strategies [Porter and Millar, 1985]. The methodology provides a high level check-list and possible prompt for IT applications by determining those value chain activities that IT can help improve. The use of information intensity matrix, which measures and compares the information inlensity of the value chain with information content of the product, is one of the tools applied in this methodology [Porter and Millar, 1985].

Customer Resource Life-Cycle (CRLC) like VCA, is an opportunity scatching framework, and the difference with VC $\wedge$ is that CRI,C focuses on a single relationship, which is the relationship between provide of goods or services and the customer. CRLC is an application diagnostic methodology, which plots the life-cycle of how a customer acquires a product or service and therefore focuses on the linkage between the supplying firm and its customers /Ives and I carmonth, 19841. The goal is to see where IT can be harness to improve customer service, with benefits to each party. The supplier uses IT to solidily its business relation with its customers, while the customer benefits from the added value of enhanced customer 
service. The major phases of the life-cycle are as follows:

1. Requirements - determining the requirements of the resource

2. Acquisition - obtaining or developing the resource

3. Stewards'ip - managing the resource while in inventory

4. Retirement - disposing of the resource.

Here the need is for frameworks which direct the analyst to ask key questions about the activity which will reveal where and how IT might produce competitive advantage. The converse use of such frameworks is to be able to test creative ideas against a sound business and strategic rubric for the activity.

The primary strength of this model is that it allows management to view each distinct step of the CRLC as opportunities for applying IT for service differentiation and thus be abie to establish a competitive advantage. However this model cannot be used as a prescriptive model in determining opportunities for the strategic use of IT [Lee and Adams, 1990]. Thus CRLC model is a post-facto model helpful in determining how IT have been used strategically and not a normative model in exploiting the strategic possibilities of IT [Lee and Aảams, 1990].

Three-Pronged Methodology (TPM), In his research, Earl [1987], suggested that the challenge is complex and hence the need for a more complex approach. He suggested three issues to be tacked by management in strategic planning of IT:

(a) Clarilication of business needs and strategy in information systems terms

(b) Evaluation of current systems provision and use

(c) Innovation of new strategic opportunities afforded by IT.

These three issues formed the basis of his three-pronged methodology (TPM) [Earl, 1989]. Earl proposed a three-pronged attack as a requirement for deriving the applicallom strategic plan. The iarst leg, of the medh. odology, addressing the first issue, is a 'lop-down' approach, which aims

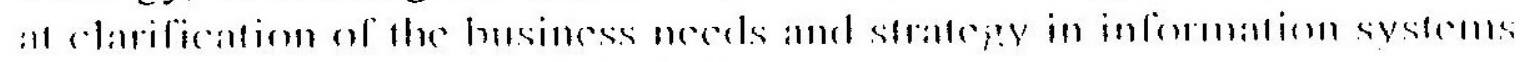

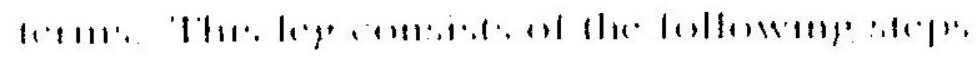


Identification and agreement of business objectives and goals for the strategic business unit using interviews and documents,

Use of the CSF methodology to explicate factors critical to success in achieving these goals,

Information systems support which these critical success factors require are determined either through the application of technology in products and processes, or the development of information systems for co-ordination and control of activities and management decision-making.

The second leg of the methodology which is a 'bottom-up' approach, aims at evaluation of current information systems provision and use. The purpose here is to demonstrate the quality and coverage of IT hitherto in order to gain, retain or regain credibility. Earl proposed the use of BSP methodology to understand existing coverage of systems, both basic business systems and management decision and support systems. He then proposed a systems audit grid as an appraisal method, to evaluate current systems on their technical quality and business value, and to decide systems for divestment, renewal, re-assessment or maintenance and enhancement. Finally, in this leg he proposed the use of SOG model to survey and audit technological experience, IT management procedures and user awareness as well as applications coverage and quality.

The third leg of the methodology which is an 'inside-out' approach, aims at innovation of new stralegic opportunitics afforded by IT. Earl proposed the use of creativity events such as think-tanks, brain-storming groups and Delphi methods to help in idea generation, which will then be subjected to some sort of feasibility and strategic validation. The use of opportunity frameworks such as VCA, CRLC, and Porter's live-forces model, for stralegic applications searching is proposed. The general principle in this leg is designing an organisational and technological environment which enables innovations to happen. 


\section{PROBLEMS WITH SIPT METHODOLOGIES}

It has long been recognised that SITP is an intricate and complex activity fraught with problems [McFarlan, 1971]. In order to organise and summarise these problems, Lederer and Sethi [ 1988], used three categories resources, process, and output. Resource-related problems addressed the issues of time-requirements, money, personnel, and top management support for the initiation of the study. Process-related problems involve the limitations of the analysis done by the methodology. Finally, output-related problems dealt with the comprehensiveness and appropriateness of the final plan produced by the methodology.

Several authors have described these problems. Their work is based on field surveys, cases, and conceptual studies, and investigates most of the methodologies described above. On the resource-related problems, Vacca, [1983], identified problems such as difficulty of finding planning team leader, difficulty of finding planning team members meeting specified criteria, difficulty of convincing top management to approve the methodology and often too large planning team required. Bowman, et al,[1983], identified too much time requirements for the planning exercise, as a resource-related problem.

Dependence on the team leader for the success of the methodology; lack of enough documentation, computer support, theoretical framework and adequate external consultant support, have also been identified as resourcerelated problems [Zachman, 1982]. Zachman also identified rigid planning procedure and failure of methodology to take into account issues related to plan implementation as process-related problems.

Output-related problems identified by Zachman includes, the difficulty involved in securing top management support and substantial further analysis required before implementing the projects and the data architecture identified in the SITP output. Failure of output to determine overall data architecture and to provide priorities for developing specific databases, and the difficulty involved in transferring the experience from implementing the methodology across divisions, were also identilied by the author as output-related problems. 
Failure to analyze the current strengths and weaknesses of the IS department, failure to take into account legal and environmental issues, and failure to assess external technological and organisation's competitive environments, have also been identified as process-related issues [King, 1984].

McLean and Soden, [1977], had earlier identified output-related problems as lack of overall personnel and training plan, and lack of financial plan for the IS department in the planning output. He also identified the outputs' failure to identify specific new projects and to provide statement of organisational objective for the IS department as output-related problems.

In a survey involving 80 US organisations, seven potential causal factors were identified as affecting the extent of the mentioned problems of SITP methodologies [Laderer and Sethi, 1988].

i. Organisations with less sophistication in business planning had more severe problems than more sophisticated organisations.

ii. Organisations with less participation by the IS department in business planning had more severe problems than organisations with greater participation.

iii. Organisations where top IS executive reported to a controller had more severe problems than organisations where the top IS executive reported to a president or vice president.

iv. Organisations where top management initiated the study had less severe problems than organisations where IS management initiated it.

v. SITP studies with a division or lunction as their scope had more severe problems than studies with the entire enterprise as their scope.

vi. When the SITP study lailed to specily a planning horizon, probfems were more severe than when it did specify a planning hori(a)11. 
vii. Publicly-owned organisations had more severe problems than privately-owned organisations.

After analysing the SITP problems and situations which wili tend to make them more severe than others, the next section will look at the situation in developing countries in relation to SITP. The purpose will be to see whether there are factors of developing countries nature which provides a marked distinction between developing and developed countries as far as SITP is concerned.

\section{SITP FACTORS OF DEVELOPING COUNTRIES NATURE}

Relevant issues for developing countries as far as SITP is concerned lies in the following facts, being a consequence of the inherent economic and social differences between these countries.

First, in the developing countries, the use of IT is still at its infant stage. Some social and economic sectors in these countries have tried, in most cases passively, to adopt some of these technologies. The success or failure of these applications is still a subject of research, as it varies from one organisation to another, from one sector to another, and from one developing country to another. What is known for sure is that these technologies have not yet been fully applied in the developing countries, and wherever they have been applied, the expected positive developments have not yet been fully achieved.

Second, expenditure in I' $\Gamma$ is meant for its two resource elements [Earl, 1989], namely the technoiogy and personnel, where technology comprises all hardware, communications and operating or packaged software, and personnel comprises all staff on IT department budgets. While investing in IT, it is very important to make sure that the Iwo resource elements are adequately covered for full exploitation and consequently highest pay off. Whein considering developing countries, the issue of the two resource ele-

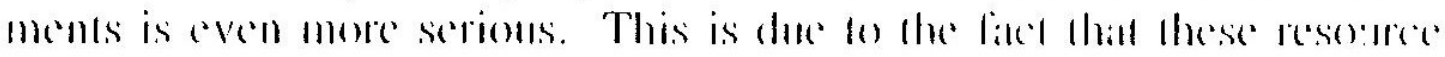
clements require financial investments, which is a major problem of the developing countrics. 
Third, to most developing countries IT will be a foreign technology as it has to be imported. This is true because computers, telecommunications equipment and most software are not made in the developing countries.

Lastly, partly because of the above reasons, the levels of education and experience on IT matters, including planning issues, for management and other staff is very low in developing countries.

Looking at these factors it is possible to conclude that the problems identified in section three will not differ too much for developing countries. However, issues of resources will likely be more severe in developing countries than in developed ones, although differing organisational situations might override this fact as finally concluded in the following section.

\section{CONCLUDING REMARKS}

With the exception of the TPM methodology, and considering the definitions of SITP and its expected outcomes, it is very logical to conclude that each of the SITP methodologies discussed deals with only a part of the problem. Essentially, one could say that most of the SITP methodologies provides a partial solution to the problem of SITP. This has been supported by Earl[Earl, 1989] in his formulation of the TPM methodology. Most of the resource, process and output related problems of SITP methodologies mentioned earlier are due to this deficiency, and therefore one would expect their severity to differ from one methodology to another.

The second major conclusion is that certain organisational specific attributes determines the severity of the mentioned SITP problems. As mentioned, lack of top management support, lower level of IS executive in the organisational hierarchy, and lack of business planning culture in organisations are among the major ones. The successful application of any of the methodologies will therefore differ from one organisation to another depending on the attributes of the nature mentioned above. Since one could not say for sure that these attributes will be more prevalent in the developing countrics than in developed countries, it is therefore inconclusive to separate the two over this issue. 
It is from the above analysis that it can finally be concluded that what has been discussed as SITP methodologies can best be considered as tools to develop SITP methodologies to suit specific situations. Various industry specific requirements will call for differing approaches in SITP and hence different combinations of the tools available. Although the criteria for selection of proper combination of these tools is highlighted here as a subject of research, it can be also be concluded that the distinction bctween developed and developing countries will be irrelevant because it will be overridden by industry specific situation factor.

\section{REFERENCES}

1. Bergeron F., Butcau C. and Raymond L., "Identification of strategic information systems opportunities: Applying and comparing two methodologies", MIS Quarterly, March 1991, pp.89-103.

2. Bokos J. Y. and Treacy M.E., "Information technology and corporate strategy: A research perspective", MIS Quarterly, June 1986, pp. 107-119.

3. Bowman B., Davis G. and Wetherbe J. "Three stage model of MIS planning" Information and Management, August 1983, pp. 11-25.

4. Boynton A.C. and Zmud R.W., "An assessment of critical success factors", Sioan Management Review, Summer 1984.

5. Boynton A.C. and Zmud R.W., "Information technology planning in the 1990's: directions for practice and research, MIS Quarterly, March 1987

6. Bullen C.V. and Rockart J.F., "A primer on critical success factcrs", (Center for Informations Research Working Paper No. 69, Sloan School of Managenent, M.I.T., Cambridge, MA, Junc 1981).

7. Clemons E.K. "Information systems for sustainable competitive advantage", Information and Management (11:3), October 1986, pp. $131-136$.

8. Danicl R.D., "Management information crisis", Havard Business Review, Sept.-Oct. 1961 pp. 111.

9. Dicbold J. "Information resource management: The new challenge", Infosystems, June 1979, pp. 115-126.

10. Earl M.J., Management Strategies for Information Technology, Prentice Hall Internationa! (LK) I.1d, 1989.

11. Earl M.J., "Information systems strategy formulation", in Boland 
R.J., Jr. and Hirschheim R. (eds), Critical Issues inInformation Research, J. Wiley, 1987.

12. Gibson C.F. and Nolan R.L. "Managing the four stages of EDP growth", Harvard Business Review, January-February 1974.

13. Holland Systems Corporation, Strategic Systems Planning", document \#M0154-04861986, Ann Arbor, MI, 1986.

14. Ives B. and Learmonth G.P., "Information system as a competitive weapon", Communications of ACM, December, 1984.

15. Johnston H.R. and Vitale M.R., "Creating competitive advantage with interorganization information systems", MIS Quarterly, June 1988, pp. 153-165.

16. King W.R., Evaluating an information systems planning process", Working Paper \#592, Graduate School of Business, University of Pittsburgh, 1984.

17. King W.R., "Strategic Planning for MIS", MIS Quarterly, March 1978.

18. Lederer A.L. and Putnam A. "Bridging the gap: Connecting systems objectives to business strategy with BSP", Journal of Information systems Management, Vol. 4, No. 3 Summer 1987, pp.40-46.

19. Lederer A.L. and Sethi V."The implementation of strategicinformation systems methodologies", MIS Quarterly, September 1988, pp.445-461.

20. Lee M.C.S. and Adams D.A., "A manager's qu:de to strategic potential of information systems", Information and Management, 19(1990), pp. 169-182.

21. Martin E.W., "Critical success factors of chief MIS/DP executives -an addendum", MIS Quarterly, December 1982, pp. 79-82.

22 McFarlan F.W. "Information technology changes the way you compete", Harvard Business Review, May-June 1984, pp. 98-103.

23. cFarlan F.W., "Problems in planning the information systems", Harvard Business Review, March-April 1971, pp. 75-89.

24. McLean E.R. and Soden J.V., Strategic Planning for MIS, J. Wiley, 1977.

25. Munro M.C., "An opinion .... comment on critical success factors work", IS Quarterly, September 1983, pp. 67-68.

26. Munro M.C. and Whecler B.R., "Planning critical success factors, and management's information requirements", MIS Quarterly, December $1980 \mathrm{pp}$. 27-38. 
27. Nolan R.L."Managing the crisis in data processing", Harverd Business Review, March-April 1979, pp. 115-126.

28. Parsons G.L., Information technology: a new competitive weapon", Sloun Management Review, Fall 1983, p. 3-14.

29. Pearson G.J., Strategic Thinking, Prentice Hall International (UK) Ltd., 1990.

30. Porter M.E., Competitive Strategy, Free Press, 1980.

31. Porter M.E. "How competitive forces shape strategy", Harvard Business Review, March-April 1979, pp. 137-145.

32. Porter M.E. and Millar V.E., "How information gives you competitive advantage", Havard Business Review, July-August, 1985.

33. Rockart J.F., "Chief executives define their own data needs", Havard Business Review, March-April 1979, pp. 84-93.

34. Rockart J.F., "The changing role of the information systems executive: A critical success factors perspective", Sloan Management Review, Fall 1982, pp. 3-13.

35. Shank M.E., Boynton A.C. and Zmud R.W., "Critical success factor analysis as a methodology for MIS planning", MIS Quarterly, June 1985.

36. Sullivan C.H. Jr., "Systems planning in the information age", Slocin Management Review, Winter 1985.

37. Truath E. "Research-oriented perspective on information management:, Journal of Systems Management, July 1984, pp.12-17.

38. Vacca J.R. "BSP: How is it working", Computerworld, March 1983.

39. Vitale M.R., Ives B., and Beath C.M., "Linking information technology and corporate strategy: An organization view", Proceedings of the Seventh International Conference on Information Systems, San Dicgo, CA, December 15-17, 1986,pp.265-276.

40. Wiscman C., Strategy and Computers: Information Systems as Competitive Weapons, Dow Jones-Irwin, Homewood, IL, 1985.

41 Zachman J.A. "Business systems planning and business information control study: A comparison", IBM Systems Journal, Volume 21, No. 1, 1982, pp. 31-53. 